\title{
Antioxidant and $\alpha$-glucosidase inhibitory effects of Pethorum chinense Purch seed extracts
}

\author{
JunHyeok Kim, Jin Hyun Im, Chung Youl Park, Da Hyun Lee, Mi Hyun Lee, \\ Young Ho Jung, Cho Hee Park, Chae Sun Na* \\ Division of Wild Plant Seeds Research, Baekdudaegan National Arboretum, Bonghwa 36209, Korea
}

\section{낙지다리(Penthorum chinense Pursh) 종자 추출물의 항산화 및 $\alpha$-glucosidase 저해 활성}

\author{
김준혁 · 임진현 · 박충열 · 이다현 · 이미현 · 정영호·박초희 · 나채선* \\ 국립백두대간수목원 야생식물종자연구실
}

\begin{abstract}
Penthorum chinense Pursh is a plant belonging to the Crassulaceae family and is a representative perennial herb that grows nationwide in watersides and wetlands. This study was conducted to enhance the competitiveness of wild plant seeds and contribute to the conservation of species diversity through the evaluation of antioxidant and antidiabetic activities of $P$. chinense seed extracts based on extraction solvents. The total phenolics content was $19.83 \mathrm{mg} \mathrm{GAE} / \mathrm{g}$ seeds in the $75 \%$ ethanol extract, whereas the flavonoid content was the highest $(10.89 \mathrm{mg} \mathrm{QE} / \mathrm{g}$ seeds) in the $75 \%$ methanol extract. Total phenolicss content was higher in the organic solvent extract than in the water extract. The DPPH radical scavenging activity was the highest $\left(\mathrm{IC}_{50} 27.60 \mu \mathrm{g} / \mathrm{mL}\right)$ in the $75 \%$ methanol extract, and the ABTS radical scavenging activity was the highest $\left(\mathrm{IC}_{50} 53.54 \mu \mathrm{g} / \mathrm{mL}\right)$ in the $75 \%$ methanol extract. Total antioxidant capacity was the highest $(30.87 \mu \mathrm{mol} \mathrm{AAE} / \mathrm{g})$ in the $75 \%$ ethanol extract. The $\alpha$-glucosidase-inhibitory activity was the highest $\left(\mathrm{IC}_{50} 46.47 \mu \mathrm{g} / \mathrm{mL}\right)$ in the $75 \%$ ethanol extract. From the results of this study, it was confirmed that $P$. chinense seed extracts, which possess high phenolics content, exhibit antioxidant and antidiabetic effects, and could be used as an effective health functional food material and natural medicine.
\end{abstract}

Key words : Penthorum chinense Pursh, antioxidant activity, $\alpha$-glucosidase inhibitory activity, wild plant seed

서 론

식물 다양성은 전례 없는 속도로 감소하고 있으며, 식물 종의 보전은 현재 세계적 우선순위이다. 하지만 동물에 비해 식물의 보전은 주목을 덜 받았으며, 결과적으로 식물은 동물 과 비교하여 보전을 위한 자원이 매우 부족하다(Havens 등, 2014). 따라서 감소하는 식물 다양성을 지키기 위해 식물자
원의 가치를 발견하고, 식물 자원의 이용 및 관심을 증진시켜 식물 보전을 위한 자원을 확대해야 한다. 현재 국내에 자생하 고 있는 식물들은 3,832종으로 알려져 있으나(Checklist of Vascular Plants in Korea Native Plants, 2021), 상업적, 농업 적 목적의 사용은 일부 종에 국한되고 있다. 따라서 이러한 식물 유전자원의 경쟁력을 높여 보전 가능성을 높이기 위한 다양한 연구들이 필요하다.

\footnotetext{
*Corresponding author. E-mail : chaesun.na@kiam.or.kr, Phone : +82-54-679-2769, Fax : +82-54-679-0630

Received 15 October 2020; Revised 12 November 2020; Accepted 28 December 2020.

Copyright (c) The Korean Society of Food Preservation.

This is an Open Access article distributed under the terms of the Creative Commons Attribution Non-Commercial License (http://creativecommons.org/licenses/by-nc/4.0) which permits unrestricted non-commercial use, distribution, and reproduction in any medium, provided the original work is properly cited.
} 
식물 유전자원의 경쟁력을 높이기 위한 수단으로 식물 추 출물 내 유용성 평가가 있다. 이러한 유용성에는 섭취하여 이 로운 효과를 보거나 화장품 원료로써 사용될 수 있는 다양한 항목들을 포함된다. 과거부터 식물유래 천연물은 다양한 질병 치료 및 증상 완화를 위해 사용되어 왔고, 그 효능이 인정되었 다(Brown, 2016). 대표적인 추출물 유래 효능으로는 섭취를 통해 체내에서 발생하는 산화 스트레스에 대한 방어능력을 나 타내는 항산화 능력과 체내 장 세포막 효소인 $\alpha$-glucosidase의 다당류를 가수분해하는 기능을 억제하여 포도당의 흡수를 억 제하는 항당뇨 능력이 있다. 식물 추출물에는 플라보노이드 를 포함하는 페놀성 화합물들을 많이 포함하는 것으로 알려 져 있는데, 이러한 2 차 대사산물은 항산화 능력 및 항당뇨 능 력을 통해 심혈관 질환, 제2형 당뇨병, 일부 유형의 암과 같은 선진국의 주요 사망 원인 및 만성 퇴행성 질환의 예방과 관련 되어 있어 최근 많은 주목을 받고 있다(Buelga 등, 2019). 결 과적으로 이러한 효능들은 2019년 국내 사망률 중 $79.8 \%$ 를 차지하여 큰 문제가 되고 있는 다양한 만성질환을 개선할 수 있을 것으로 기대된다(KDCA, 2019; Zhang 등, 2015).

낙지다리(Penthorum chinense Pursh)는 물가나 습지에서 전국적으로 자생하는 대표적인 다년생 초본이다. 현재 낙지다 리의 식물체를 대상으로 중국에서는 항산화, 항염, 간보호 효 능이 밝혀졌으며(Hu 등, 2015; Lin 등, 2018; Xia 등, 2012), 국내에서도 알레르기 억제효과(Jo와 Kim, 2015)와 콜라겐 성 분을 안정화시켜 피부 노화 예방 효능이 있다고 알려진 (-)-epicatechin gallate 성분의 존재가 보고되었다(Kwon 등, 2019). 하지만 이러한 유용성 평가는 식물체를 대상으로만 진행되었으며, 낙지다리 종자에 관한 실험은 전무하다.

따라서 본 연구는 낙지다리 종자 추출물의 다양한 항산화 와 항당뇨 활성 평가를 통하여 천연 항산화 및 항당뇨의 기능 성 식품과 약품 소재로서의 활용에 있어 기초자료로 사용하 며, 더 나아가 야생식물의 경쟁력을 높여 식물 다양성 보전에 기여하고자 하였다.

\section{재료 및 방법}

\section{실험 재료 및 시료 추출}

본 실험에 사용된 낙지다리 종자는 국립세종수목원에서 2019년에 수집된 종자를 사용하였다. 추출 전 낙지다리 종자 의 $25 / 15^{\circ} \mathrm{C}(12 / 12 \mathrm{~h})$ 에서 최종발아율 $89 \pm 5 \%$ 를 확인하였다. 시료의 추출은 물, $75 \%$ 에탄올, $75 \%$ 메탄올 추출을 하였다. 물 추출물은 증류수 10 배의 양을 가하여 $40^{\circ} \mathrm{C}$ 의 shaking incubator(JSSI-100C, JSR, Gongju, Korea)에서 2일(48 h)간 추출하였다. $75 \%$ 에탄올, $75 \%$ 메탄올 추출물은 각각의 10 배 의 양을 가하여 상온의 shaking incubator에서 2 일(48 h)간 추 출하였다. 제조된 추출물은 여과지(No.20, $110 \mathrm{~mm}$, Hyundai
Micro Co., Seoul, Korea)를 이용하여 여과한 후 Eyela evaporator(CVE-3110, EYELA, Tokyo, Japan)로 감압 농축 하여 용매를 완전히 제거한 후 distilled water와 dimethyl sulfoxide(DMSO, Sigma Chemical Co., St. Louis, MO, $\mathrm{USA}$ 로 녹여 $-20^{\circ} \mathrm{C}$ 에 보관하면서 본 실험에 사용하였다. 추 출 수율은 물, $75 \%$ 에탄올, $75 \%$ 메탄올이 각각 $3.73 \pm 0.1$, $6.58 \pm 0.0,5.73 \pm 0.0 \%$ 로 나타났다.

\section{총페놀성 화합물 함량 측정}

총페놀성 화합물 함량은 Ainsworth와 Gillespie(2007)의 방법에 따라 측정하였다. 시료 $20 \mu \mathrm{L}$ 에 $40 \mu \mathrm{L}$ 의 증류수에 녹 인 0.4 N Folin \& Ciocalteu's phenol reagent(Sigma Chemical Co.)를 넣어준 후 5 분간 방치한 후, $140 \mu \mathrm{L}$ 의 $700 \mathrm{mM}$ $\mathrm{Na}_{2} \mathrm{CO}_{3}$ 를 넣어주고 상온에서 2시간 반응 후 microplate reader(Multiskan go, Thermo Scientific, Vantaa, Finland)를 이용하여 $765 \mathrm{~nm}$ 에서 반응액의 흡광도를 측정하였다. 표준 물질로 gallic acid(Sigma Chemical Co.)를 희석하여 검량선 을 만들어, 추출물 내 총페놀성 화합물 함량을 분석하였다.

\section{총플라보노이드 함량 측정}

총플라보노이드 함량은 Chang 등(2002)의 방법에 따라 측 정하였다. $100 \mu \mathrm{L}$ 시료에 $300 \mu \mathrm{L} \mathrm{EtOH(Daejung,} \mathrm{Siheung,}$ Korea), $20 \mu \mathrm{L}$ 의 $1 \mathrm{M}$ potassium acetate(Junsei Chemical Co., Tokyo, Japan), $20 \mu \mathrm{L}$ 의 $10 \%$ aluminum chloride $\left(\mathrm{AlCl}_{3}\right.$, Junsei Chemical Co.), $560 \mu \mathrm{L}$ 의 증류수를 넣고 혼합한 후 상온에서 30분간 반응시킨 후 96-well plate에 분주 후 microplate reader(Multiskan go, Thermo Scientific)를 이용 하여 $415 \mathrm{~nm}$ 에서 반응액의 흡광도를 측정하였다. 표준물질 로 quercetin(Sigma Chemical Co.)을 희석하여 검량선을 만 들어, 추출물 내 총플라보노이드 함량을 분석하였다.

\section{$\mathrm{DPPH}$ 라디칼 소거능 평가}

$\mathrm{DPPH}$ 라디컬 소거능 평가는 항산화 능력을 평가하는데 가장 많이 사용되는 방법으로 자유라디칼을 가지며 보라색을 띄는 DPPH 분자가 수소공여능이 우수한 시료와 혼합되었을 때 황색을 띄는 환원된 형태로 변하는 특성을 이용하여 항산화 능력을 평가하는 방법이다(Alam 등, 2012). DPPH radical 소거 활성은 Molyneux 등(2004)의 방법을 참고하여 사용하였다. 시 료 $50 \mu \mathrm{L}$ 에 $150 \mu \mathrm{L}$ 의 $0.1 \mathrm{mM}$ 1,1-diphenyl-2-picrylhydrazyl (DPPH, Alfa Aesar, MS, USA) radical 용액을 혼합하여 30분 간 암소에서 반응시켰다. 그 후에 microplate reader(Multiskan Go, Thermo scientific)를 이용하여 $517 \mathrm{~nm}$ 에서 반응액의 흡 광도를 측정하였다. 시료 Blank는 시료를 처리하지 않고 시 료 희석 용매를 첨가한 것으로 하여 아래와 같은 방법으로 흡광도를 측정하였다. DPPH 라디칼 소거능은 아래의 식에 
따라 백분율로 나타낸 후 $50 \%$ 의 소거능을 나타내는 시료 농 도인 $\mathrm{IC}_{50}$ 값을 구하였다. 양성대조군으로 ascorbic acid (Fujifilm Wako Pure Chemical Co., Osaka, Japan)을 사용하 여 $\mathrm{IC}_{50}$ 을 제시하였다.

$\mathrm{DPPH}$ 라디칼 소거능 $(\%)=$

$$
\text { (1- } \left.\frac{\text { 시료첨가구의 흡광도 }}{\text { 무첨가구의 흡광도 }}\right) \times 100
$$

\section{ABTS 라디칼 소거능 평가}

$\mathrm{ABTS}$ 라디컬 소거능 평가는 $\mathrm{ABTS}$ 염과 강력한 산화제인 potassium persulfate와 반응하여 생성되는 청록색의 ABTS 발색단이 수소공여능이 우수한 시료에 의해 환원될 때 변색 되는 특성을 이용하여 항산화 능력을 평가하는 방법이다 (Hernandez-Rodriguez 등, 2019). 2,2'-azinobis(3-ethylbenzothiazoline-6-sulfonic acid)(ABTS) radical 소거능은 Pellegrini 등(1999)의 방법을 변형하여 측정하였다. 증류수 $5 \mathrm{~mL}$ 에 $140 \mathrm{mM}$ potassium persulfate $\left(\mathrm{K}_{2} \mathrm{~S}_{2} \mathrm{O}_{8}\right.$, Acros oragnics, Geel, Belgium) $88 \mu \mathrm{L}$ 를 가한 혼합 시약에 $\mathrm{ABTS}$ diammonium salt tablet(Sigma Chemical Co.) 2알을 넣어 $7 \mathrm{mM} \mathrm{ABTS}$ 수 용액을 만들어 암실에 14-16시간 방치시킨 후, 이를 에탄올 과 $1: 88$ 의 비율로 섞어 $734 \mathrm{~nm}$ 에서 측정한 흡광도 값이 $0.70 \pm 0.02$ 가 되도록 조절한 $\mathrm{ABTS}$ solution을 시약으로 사용 하였다. 시료 $10 \mu \mathrm{L}$ 와 ABTS solution $190 \mu \mathrm{L}$ 를 96-well plate에 분주한 후 2 분 30 초간 반응하여 microplate reader (Multiskan Go, Thermo scientific)를 이용하여 $734 \mathrm{~nm}$ 에서 반응액의 흡광도를 측정하였다. 시료 무첨가구는 시료를 처 리하지 않고 시료 희석 용매를 첨가한 것으로 하여 위와 같은 방법으로 흡광도를 측정하였다. ABTS 라디칼 소거능은 아래 의 식에 따라 백분율로 나타낸 후 $50 \%$ 의 소거능을 나타내는 시료 농도인 $\mathrm{IC}_{50}$ 값을 구하였다. 양성대조군으로 2,6-di-tertbutyl-4-methylphenol(BHT, Sigma Chemical Co.)을 사용하 여 $\mathrm{IC}_{50}$ 을 제시하였다.

$\mathrm{ABTS}$ 라디칼 소거능 $(\%)=$

$$
\text { (1- } \left.\frac{\text { 시료첨가구의 흡광도 }}{\text { 무첨가구의 흡광도 }}\right) \times 100
$$

\section{총항산화 능력 평가}

Phosphomolybdenum 분석 방법은 시료에 의해 $\mathrm{Mo}(\mathrm{VI})$ 가 $\mathrm{Mo}(\mathrm{V})$ 로 환원되어 산성 $\mathrm{pH}$ 에서 녹색의 phosphate $\mathrm{Mo}(\mathrm{V})$ 복합체를 생성하는 특성을 이용하여 항산화 능력을 평가하는 방법이다(Alam 등, 2013). 총항산화 능력은 Prieto 등(2013)의 phosphomolybdenum 분석 방법에 따라 측정하였다. 0.588 $\mathrm{mL}$ 의 sulphuric acid(Kanto Chemical Co., Tokyo, Japan)에
$0.049 \mathrm{~g}$ ammonium molybdate(Kanto Chemical Co.)와 $0.036 \mathrm{~g}$ sodium phosphate(Daejung)를 넣고 증류수로 $10 \mathrm{~mL}$ 의 부피를 맞춰준 solution을 시약으로 사용하였다. 시료 10 $\mu \mathrm{L}$ 와 시약 $190 \mu \mathrm{L}$ 를 96-well microplate에 분주한 후 $95^{\circ} \mathrm{C}$ 에 서 1시간 반응시킨 후 microplate reader(Multiskan Go, Thermo Scientific)를 이용하여 $695 \mathrm{~nm}$ 에서 반응액의 흡광도를 측정 하였다. 표준물질로 ascorbic acid(Fujifilm Wako Pure Chemical Co.)를 희석하여 검량선을 만들어, 추출물 내 총항 산화 능력을 분석하였다.

\section{$\alpha$-Glucosidase 저해활성 평가}

$\alpha$-Glucosidase 저해활성은 Agada 등(2020)의 방법에 따 라 측정하였다. 1 unit $/ \mathrm{mL}$ 의 $\alpha$-glucosidase(Millipore Sigma, Burlington, MA, USA) $50 \mu \mathrm{L}$ 에 농도별 시료액 $20 \mu \mathrm{L}$ 를 넣 고 $37^{\circ} \mathrm{C}$ 에서 사전 반응시킨 후, $5 \mathrm{mM} p$-nitrophenyl glucopyranoside(pNPG, Millipore Sigma) $30 \mu \mathrm{L}$ 를 넣고 $37^{\circ} \mathrm{C}$ 에서 60 분간 반응시킨다. 반응액에 $0.1 \mathrm{M}$ sodium carbonate $\left(\mathrm{Na}_{2} \mathrm{CO}_{3}\right.$, Daejung) $1,000 \mu \mathrm{L}$ 를 넣어 반응을 정지시킨 후 microplate reader(Multiskan Go, Thermo Scientific)를 이용 하여 $400 \mathrm{~nm}$ 에서 흡광도를 측정하였다. Blank는 $\mathrm{pNPG}$ 를 첨 가하기 전 혼합물에 $\mathrm{Na}_{2} \mathrm{CO}_{3}$ 를 먼저 첨가하여 사용하였으며, 양성대조군은 acarbose(Tokyo Chemical Industry Co., Tokyo, $\mathrm{Japan}$ )를 사용하여 $\mathrm{IC}_{50}$ 을 제시하였다.

$\alpha$-Glucosidase 저해활성은 아래의 식에 따라 백분율로 나 타낸 후 $50 \%$ 의 저해율을 나타내는 시료 농도인 $\mathrm{IC}_{50}$ 값을 구 하였다.

$$
\begin{aligned}
& \alpha \text {-Glucosidase 저해율 }(\%)= \\
& \left(1-\frac{\text { 시료첨가구의 흡광도 }}{\text { 무첨가구의 흡광도 }}\right) \times 100
\end{aligned}
$$

\section{통계분석}

모든 실험은 3 회 반복하였으며, 실험 결과 분석은 SPSS v.23(IBM, Armonk, NY, USA)을 이용하여 일원배치 분산분 석을 실시하였고, Duncan's multiple range test를 이용하여 집단 간 유의성을 $\mathrm{p}<0.05$ 수준에서 검정하였다. 또한 독립표 본 $\mathrm{t}$ 검정을 이용하여 두 집단 간 유의성을 검정하였다.

\section{결과 및 고찰}

\section{낙지다리 종자 추출물의 페놀성 화합물 함량}

낙지다리 종자를 유기용매 및 물을 이용한 각 추출물을 대 상으로 총페놀성 화합물 함량 및 총플라보노이드 함량을 측 정하였다(Table 1). 그 결과, 낙지다리 종자 물, $75 \% \mathrm{EtOH}$, $75 \% \mathrm{MeOH}$ 추출물의 페놀성 화합물 함량은 각각 8.97 , 
$19.83,18.66 \mathrm{mg} \mathrm{GAE} / \mathrm{g}$ seeds로, $\mathrm{EtOH}, \mathrm{MeOH}$, 물 추출물 순으로 페놀성 화합물을 많이 함유하는 것으로 나타났다. 총 플라보노이드 함량의 경우, 물, $75 \% \mathrm{EtOH}, 75 \% \mathrm{MeOH}$ 추 출물의 함량은 $1.99,9.96,10.89 \mathrm{mg} \mathrm{QE} / \mathrm{g}$ seeds로 $\mathrm{MeOH}$, $\mathrm{EtOH}$, 물 추출물 순으로 플라보노이드를 많이 함유하는 것 으로 나타났다. 결과적으로 낙지다리 종자의 페놀성 화합물 과 플라보노이드 추출은 물 추출보다는 $\mathrm{MeOH}, \mathrm{EtOH}$ 와 같 은 유기용매를 이용한 추출이 더 효과적인 것으로 나타났다. 하지만 호박 종자의 경우, 유기용매보다 물 추출물에서 많게 는 2배 이상 더 높게 나타나기도 하거나(Xanthopoulou 등, 2009), 석류 종자에서는 반대로 $\mathrm{MeOH}$ 추출물에서 물 추출 물보다 더 높게 나타나기도 하여(Elfalleh 등, 2012), 용매에 따른 총페놀성 화합물의 추출 효과는 종에 따라 다른 것으로 판단된다. 가장 높게 분석된 총페놀성 화합물 함량은 $75 \%$ $\mathrm{EtOH}$ 추출물의 $19.83 \mathrm{mg} \mathrm{GAE} / \mathrm{g}$ 으로 기존에 보고된 미선나 무 종자의 ethyl acetate 분획물(17.03 mg TAE/g), 아마란스 종자의 물 추출물 $(4.23 \mathrm{mg} \mathrm{GAE} / \mathrm{g})$, 석류 종자 $\mathrm{MeOH}$ 추출 물(11.84 mg GAE/g)보다 높게 나타났다(Elfalleh 등, 2012; Jang과 Park, 2017; Jo 등, 2014).

\section{낙지다리 종자 추출물의 DPPH 라디컬 소거능}

낙지다리 종자 추출물의 항산화 활성을 측정하기 위해 $\mathrm{DPPH}$ 라디컬 소거능 평가를 수행하였다(Table 2). 낙지다리

Table 1. Total phenolics and flavonoid contents of $P$. chinense Purch seed extracts using different extraction solvent

\begin{tabular}{ccc}
\hline $\begin{array}{c}\text { Extraction } \\
\text { solvent }\end{array}$ & $\begin{array}{c}\text { Total phenolics content Total flavonoid content } \\
\left(\mathrm{mg} \mathrm{GAE}^{1)} / \mathrm{g} \text { seeds }\right)\end{array}$ & $\begin{array}{c}\left(\mathrm{mg} \mathrm{QE}^{1)} / \mathrm{g} \text { seeds }\right) \\
\text { Water }\end{array}$ \\
\hline $\left.5.97 \pm 0.29^{\mathrm{c} 2}\right)$ & $1.99 \pm 0.10^{\mathrm{c}}$ \\
$75 \%$ ethanol & $19.83 \pm 0.07^{\mathrm{a}}$ & $9.96 \pm 0.25^{\mathrm{b}}$ \\
$75 \%$ methanol & $18.66 \pm 0.19^{\mathrm{b}}$ & $10.89 \pm 0.19^{\mathrm{a}}$ \\
\hline
\end{tabular}

${ }^{1)} \mathrm{GAE}$, equivalent to gallic acid; QE, quercetin.

${ }^{2)} \mathrm{Mean} \pm \mathrm{SE}(\mathrm{n}=3)$ within each column followed by different letters are significantly different $(\mathrm{p}<0.05)$.
종자 물, $75 \% \mathrm{EtOH}, 75 \% \mathrm{MeOH}$ 추출물의 $\mathrm{DPPH}$ 라디칼 소거 능 $\mathrm{IC}_{50}$ 값은 각각 $42.65,30.09,27.60 \mu \mathrm{g} / \mathrm{mL}$ 로 나타났다. 결과 적으로 $\mathrm{MeOH}, \mathrm{EtOH}$, 물 추출물 순으로 $\mathrm{DPPH}$ 라디컬 소거능 이 높은 것으로 나타났으며, 특히 $75 \% \mathrm{MeOH}$ 추출물에서 가장 강한 DPPH 라디칼 소거능이 나타났다. 그러나 강력한 항산화 제로 알려진 본 실험의 대조구 L-ascorbic acid(Padayatty 등, 2003)의 $\mathrm{IC}_{50}$ 인 $20.00 \mu \mathrm{g} / \mathrm{mL}$ 보다는 낮은 활성을 나타냈다.

\section{낙지다리 종자 추출물의 ABTS 라디컬 소거능}

낙지다리 종자 추출물의 항산화 활성을 측정하기 위해 ABTS 라디컬 소거능 평가를 수행하였다(Table 3). 낙지다리 종자 물, $75 \% \mathrm{EtOH}, 75 \% \mathrm{MeOH}$ 추출물의 $\mathrm{ABTS}$ 라디칼 소거능 $\mathrm{IC}_{50}$ 값은 각각 $72.13,58.31,53.54 \mu \mathrm{g} / \mathrm{mL}$ 로 나타났 다. 결과적으로 $\mathrm{DPPH}$ 라디컬 소거능 평가와 마찬가지로 $\mathrm{MeOH}, \mathrm{EtOH}$, 물 추출물 순으로 $\mathrm{ABTS}$ 라디컬 소거능이 높 게 나타났으며, 특히 $75 \% \mathrm{MeOH}$ 추출물에서 가장 강한 $\mathrm{ABTS}$ 라디컬 소거능을 확인하였으며, 앞선 결과와 마찬가 지로 물 추출물보다는 유기용매 추출물에서 더 높은 활성을 나타냈다. 광범위하게 사용되는 항산화제인 BHT (Yehye 등, 2015)의 $\mathrm{IC}_{50}$ 인 $13.70 \mu \mathrm{g} / \mathrm{mL}$ 보다는 낮은 활성이 나타났다.

\section{낙지다리 종자 추출물의 총항산화능}

낙지다리 종자 추출물의 항산화 활성을 측정하기 위해 phosphomolybdenum 방법을 이용한 총항산화 능력을 평가 하였다(Table 4). 낙지다리 종자 물, $75 \% \mathrm{EtOH}, 75 \% \mathrm{MeOH}$ 추출물의 최종 농도 $50 \mathrm{ppm}$ 일 때의 총항산화 능력은 27.26 , $30.87,28.88 \mu \mathrm{mol} \mathrm{AAE} / \mathrm{g}$ 으로 $75 \%$ 에탄올 추출물에서 가장 높게 나타났다. 하지만 이러한 항산화 능력은 기존에 보고된 포도 종자의 총항산화 능력과 비교하였을 때 낮은 수준인 것 으로 나타났다(Jayaprakasha 등, 2002). 본 실험의 결과, phosphomolybdenum 분석을 기준으로 하면 낙지다리 종자 추출물의 총 항산화 활성은 낮은 것으로 판단되며, 다양한 농 도에서 추가적인 분석이 필요할 것으로 생각된다.

앞선 항산화 능력 평가 결과를 종합적으로 생각해보면, 항

Table 2. DPPH radical scavenging activities of $P$. chinense Purch seed extracts using different extraction solvent

\begin{tabular}{|c|c|c|c|c|c|c|}
\hline \multirow{2}{*}{$\begin{array}{c}\text { Extraction } \\
\text { solvent }\end{array}$} & \multicolumn{4}{|c|}{ Scavenging activity (\%) } & \multirow{2}{*}{$\mathrm{IC}_{50}(\mu \mathrm{g} / \mathrm{mL})$} & \multirow{2}{*}{$\begin{array}{l}\text { Ascorbic acid }{ }^{1)} \\
\mathrm{IC}_{50}(\mu \mathrm{g} / \mathrm{mL})\end{array}$} \\
\hline & $50(\mu \mathrm{g} / \mathrm{mL})$ & $40(\mu \mathrm{g} / \mathrm{mL})$ & $20(\mu \mathrm{g} / \mathrm{mL})$ & $10(\mu \mathrm{g} / \mathrm{mL})$ & & \\
\hline Water & $58.62 \pm 1.99^{\mathrm{b} 2)}$ & $45.95 \pm 1.79^{\mathrm{b}}$ & $28.29 \pm 1.50^{b}$ & $12.80 \pm 0.42^{\mathrm{c}}$ & $42.65 \pm 1.58^{\mathrm{a}}$ & \\
\hline $75 \%$ ethanol & $73.92 \pm 1.18^{\mathrm{a}}$ & $64.38 \pm 1.09^{\mathrm{a}}$ & $42.45 \pm 0.49^{\mathrm{a}}$ & $22.46 \pm 0.19^{b}$ & $30.09 \pm 0.42^{\mathrm{b}}$ & $20.00 \pm 0.48$ \\
\hline $75 \%$ methanol & $77.99 \pm 1.00^{\mathrm{a}}$ & $69.40 \pm 2.19^{\mathrm{a}}$ & $45.74 \pm 0.77^{\mathrm{a}}$ & $24.78 \pm 0.47^{\mathrm{a}}$ & $27.60 \pm 0.13^{\mathrm{b}}$ & \\
\hline
\end{tabular}

\footnotetext{
${ }^{1)}$ Ascorbic acid was used as a positive control.

${ }^{2)}$ Mean \pm SE ( $\left.n=3\right)$ within each column followed by different letters are significantly different $(\mathrm{p}<0.05)$.
} 
Table 3. ABTS radical scavenging activities of $P$. chinense Purch seed extracts using different extraction solvent

\begin{tabular}{|c|c|c|c|c|c|c|}
\hline \multirow{2}{*}{$\begin{array}{c}\text { Extraction } \\
\text { solvent }\end{array}$} & \multicolumn{4}{|c|}{ Scavenging activity (\%) } & \multirow{2}{*}{$\mathrm{IC}_{50}(\mu \mathrm{g} / \mathrm{mL})$} & \multirow{2}{*}{$\begin{array}{c}\mathrm{BHT}^{1)} \\
\mathrm{IC}_{50}(\mu \mathrm{g} / \mathrm{mL})\end{array}$} \\
\hline & $100(\mu \mathrm{g} / \mathrm{mL})$ & $50(\mu \mathrm{g} / \mathrm{mL})$ & $25(\mu \mathrm{g} / \mathrm{mL})$ & $12.5(\mu \mathrm{g} / \mathrm{mL})$ & & \\
\hline Water & $65.18 \pm 0.65^{\mathrm{c} 2)}$ & $40.18 \pm 1.58^{b}$ & $20.91 \pm 1.03^{\mathrm{c}}$ & $9.73 \pm 0.30^{\mathrm{c}}$ & $72.13 \pm 1.53^{\mathrm{a}}$ & \\
\hline $75 \%$ ethanol & $72.32 \pm 0.57^{\mathrm{b}}$ & $53.31 \pm 0.68^{\mathrm{a}}$ & $28.66 \pm 0.42^{\mathrm{b}}$ & $14.07 \pm 0.60^{\mathrm{b}}$ & $58.31 \pm 0.33^{\mathrm{b}}$ & $13.70 \pm 0.51$ \\
\hline $75 \%$ methanol & $76.15 \pm 0.98^{\mathrm{a}}$ & $56.57 \pm 2.63^{\mathrm{a}}$ & $32.17 \pm 0.36^{\mathrm{a}}$ & $16.61 \pm 0.11^{\mathrm{a}}$ & $53.54 \pm 1.64^{\mathrm{c}}$ & \\
\hline
\end{tabular}

${ }^{1)}$ 2,6-Di-tert-butyl-4-methylphenol (BHT) was used as a positive control.

${ }^{2} \operatorname{Mean} \pm \operatorname{SE}(\mathrm{n}=3)$ within each column followed by different letters are significantly different $(\mathrm{p}<0.05)$.

Table 4. Total antioxidant capacity of $P$. chinense Purch seed extracts using different extraction solvent

\begin{tabular}{cc}
\hline Extraction solvent & $\begin{array}{c}\text { Total antioxidant capacity } \\
(\mu \mathrm{mol} \mathrm{AAE} / \mathrm{g})\end{array}$ \\
\hline Water & $27.26 \pm 0.85^{\mathrm{a} 2)}$ \\
$75 \%$ ethanol & $30.87 \pm 0.83^{\mathrm{a}}$ \\
$75 \%$ methanol & $28.88 \pm 1.67^{\mathrm{a}}$ \\
\hline
\end{tabular}

${ }^{1)} \mathrm{AAE}$, quivalent to ascorbic acid.

${ }^{2)} \mathrm{Mean} \pm \mathrm{SE}(\mathrm{n}=3)$ within each column followed by different letters are significantly different $(\mathrm{p}<0.05)$.

산화 분석 방법에 따라서 차이는 있지만, 유기용매를 이용한 낙지다리 종자 추출물은 식물 소재의 천연 항산화제로서 높 은 가능성을 가질 것으로 기대된다. 또한, 높은 항산화능력을 갖는 종자 추출물이 항균, 미백, 항암 활성이 나타내는 것으 로 확인되어 낙지다리 종자 추출물 또한 다양한 생리활성 효 능과 연관이 있을 것으로 생각된다(Baydar 등, 2005; Islam 등, 2013; Jang과 Park, 2017).

\section{낙지다리 종자 추출물의 $\alpha$-glucosidase 저해활성}

$\alpha$-Glucosidase 효소는 소장 내의 이당류, 올리고당 등을 포 도당으로 분해하는 효소로, acarbose와 같은 당과 유사한 구 조를 가지나, 분해되지 않는 물질이 효소의 탄수화물 결합 부
위에 대신 결합하여 효소의 활성을 억제함으로써 포도당의 장 흡수를 지연시켜 항당뇨 효과를 나타낸다(Bischoff, 1995). 낙 지다리 종자 추출물의 항당뇨 활성을 측정하기 위해 $\alpha$ glucosidase 저해활성을 평가하였다(Table 5). 낙지다리 종자 $75 \% \mathrm{EtOH}, 75 \% \mathrm{MeOH}$ 추출물의 $\alpha$-glucosidase 저해활성 $\mathrm{IC}_{50}$ 은 $46.47,70.97 \mu \mathrm{g} / \mathrm{mL}$ 로 나타나 $75 \% \mathrm{EtOH}$ 추출물에서 활성이 가장 높게 나타났으며, 물 추출물은 매우 낮은 활성을 확인하였다. 항당뇨제로 사용하고 있는 본 실험의 대조구인 acarbose (Clissold와 Edwards, 1988)의 $\mathrm{IC}_{50}$ 는 $33.77 \mu \mathrm{g} / \mathrm{mL}$ 로, 낙지다리 종자 추출물이 대조구보다 활성이 낮게 나타났다.

본 연구는 야생식물 자원의 유용성을 평가하여 보전가능 성을 높이기 위해 낙지다리 종자를 대상으로 항산화 및 항당 뇨 능력을 평가하였다. 이상의 연구 결과, 낙지다리 종자를 효율적으로 추출하기 위해서는 물보다는 유기용매로 추출하 는 것이 효과적이며, 마찬가지로 유기용매에서 가장 우수한 항산화 활성 및 $\alpha$-glucosidase 저해활성을 나타내었다. 이러 한 결과를 통해 낙지다리를 포함하는 야생식물자원에 대한 관심과 이용이 높아져 생물다양성의 보전 가능성 증진에 도 움이 될 것으로 생각된다.

\section{요 약}

낙지다리는 돌나물과에 속하는 식물로 물가나 습지에서

Table 5. $\alpha$-Glucosidase inhibition activities of $P$. chinense Purch seed extracts using different extraction solvent

\begin{tabular}{|c|c|c|c|c|c|c|c|}
\hline \multirow{2}{*}{ Extraction solvent } & \multicolumn{5}{|c|}{ Inhibition activity (\%) } & \multirow{2}{*}{$\mathrm{IC}_{50}(\mu \mathrm{g} / \mathrm{mL})$} & \multirow{2}{*}{$\begin{array}{c}\text { Acarbose }{ }^{1)} \\
\mathrm{IC}_{50}(\mu \mathrm{g} / \mathrm{mL})\end{array}$} \\
\hline & $100(\mu \mathrm{g} / \mathrm{mL})$ & $50(\mu \mathrm{g} / \mathrm{mL})$ & $25(\mu \mathrm{g} / \mathrm{mL})$ & $12.5(\mu \mathrm{g} / \mathrm{mL})$ & $6.25(\mu \mathrm{g} / \mathrm{mL})$ & & \\
\hline Water & $5.26 \pm 0.8^{\mathrm{c} 2)}$ & $5.22 \pm 1.7^{\mathrm{b}}$ & $4.21 \pm 0.2^{\mathrm{c}}$ & $4.05 \pm 0.4^{b}$ & $0.96 \pm 2.1^{\mathrm{a}}$ & $\mathrm{ND}^{3)}$ & \\
\hline $75 \%$ ethanol & $84.19 \pm 0.7^{\mathrm{a}}$ & $60.46 \pm 4.1^{\mathrm{a}}$ & $42.75 \pm 1.5^{\mathrm{a}}$ & $18.53 \pm 3.4^{\mathrm{a}}$ & $10.69 \pm 7.3^{\mathrm{a}}$ & $46.47 \pm 2.3^{* * 4)}$ & $33.77 \pm 3.8$ \\
\hline $75 \%$ methanol & $59.12 \pm 3.1^{\mathrm{b}}$ & $46.80 \pm 5.7^{\mathrm{a}}$ & $17.00 \pm 3.9^{b}$ & $8.24 \pm 2.6^{\mathrm{b}}$ & $4.79 \pm 3.7^{\mathrm{a}}$ & $70.97 \pm 2.3$ & \\
\hline
\end{tabular}

${ }^{1)}$ Acarbose was used as a positive control.

${ }^{2)}$ Mean \pm SE $(n=3)$ within each column followed by different letters are significantly different $(\mathrm{p}<0.05)$

${ }^{3)} \mathrm{ND}$, not detected.

${ }^{4)}$ Mean $\pm \mathrm{SE}(\mathrm{n}=3)$ within each column followed by ${ }^{* *}$ means $\mathrm{p}<0.01$ by independent $\mathrm{t}$-test. 
전국적으로 자생하는 대표적인 다년생 초본이다. 본 연구는 낙지다리 종자 추출물의 추출용매에 따른 항산화 및 항당뇨 활성 평가를 통해 야생식물 종자의 경쟁력을 높이는 한편, 종 다양성 보전에 기여하기 위해 진행되었다. 낙지다리 종자 추 출물 내 총페놀성 화합물의 함량은 $75 \% \mathrm{EtOH}$ 추출물에서 $19.83 \mathrm{mg} \mathrm{GAE} / \mathrm{g}$ seeds, 총플라보노이드 함량은 $75 \% \mathrm{MeOH}$ 추출물에서 $10.89 \mathrm{mg} \mathrm{QE} / \mathrm{g}$ seeds로 가장 높게 나타났다. 용 매에 따른 페놀성 물질은 물 추출물에 비해 유기용매 추출물 에서 더 높은 것으로 확인되었다. 낙지다리 종자 추출물의 $\mathrm{DPPH}$ 라디컬 소거능의 $\mathrm{IC}_{50}$ 은 $75 \% \mathrm{MeOH}$ 추출물에서 27.60 $\mu \mathrm{g} / \mathrm{mL}$ 로 가장 높게 났으며, $\mathrm{ABTS}$ 라디컬 소거능의 $\mathrm{IC}_{50}$ 은 $53.54 \mu \mathrm{g} / \mathrm{mL}$ 로 $75 \% \mathrm{MeOH}$ 추출물에서 가장 높게 나타났다. 낙지다리 종자 추출물의 총항산화 능력은 $30.87 \mu \mathrm{mol}$ $\mathrm{AAE} / \mathrm{g}$ 으로 $75 \% \mathrm{EtOH}$ 추출물에서 가장 높게 나타났다. 낙 지다리 종자 추출물의 $\alpha$-glucosidase 저해활성 $\mathrm{IC}_{50}$ 은 $75 \%$ $\mathrm{EtOH}$ 추출물에서 $46.47 \mu \mathrm{g} / \mathrm{mL}$ 로 가장 높게 나타났다. 본 연 구결과를 통해 풍부한 페놀성 물질을 가진 낙지다리 종자의 유기용매 추출물이 항산화와 항당뇨 효과를 나타낸다는 것을 확인하였으며, 이는 효과적인 건강기능식품 소재 및 천연물 의약품으로서 이용할 수 있을 것으로 기대한다.

\section{감사의 글}

This study was carried out with support from the R\&D Program for Forest Science Technology (Project No. 2021400B10-2125-CA02), provided by the Korea Forest Service.

\section{Conflict of interests}

The authors declare no potential conflict of interest.

\section{ORCID}

JunHyeok Kim https://orcid.org/0000-0002-9490-7054

Chae Sun Na https://orcid.org/0000-0002-7936-2121

\section{References}

Agada R, Usman WA, Shehu S, Thagariki D. In vitro and in vivo inhibitory effects of Carica papaya seed on $\alpha$ amylase and $\alpha$-glucosidase enzymes. Heliyon, 6, e03618 (2020)

Ainsworth EA, Gillespie KM. Estimation of total phenolic content and other oxidation substrates in plant tissues using Folin-Ciocalteu reagent. Nat Protoc, 2, 875- 877 (2007)

Alam MN, Bristi NJ, Rafiquzzaman M. Review on in vivo and in vitro methods evaluation of antioxidant activity. Saudi Pharm J, 21, 143-152 (2013)

Baydar NG, Sagdic O, Ozkan G, Cetin S. Determination of antibacterial effects and total phenolic contents of grape (Vitis vinifera L.) seed extracts. Int J Food Sci Technol, 41, 799-804 (2006)

Bischoff $\mathrm{H}$. The mechanism of alpha-glucosidase inhibition in the management of diabetes. Clin Invest Med, 18, 303-311 (1995)

Brown AC. An overview of herb and dietary supplement efficacy, safety and government regulations in the United States with suggested improvements. Part 1 of 5 series. Food Chem Toxicol, 107, 449-471 (2017)

Chang CC, Yang MH, Wen HM, Chern JC. Estimation of total flavonoid content in propolis by two complementary colorimetric methods. J Food Drug Anal, 10, 178-182 (2002)

Chung KH, Jo HJ, Yoon JA, Song BC, An JH. Free radicalscavenging activities of amaranth (Amaranthus spp. L.) seed extracts. Food Eng Prog, 18, 116-123 (2014)

Clissold SP, Edwards C. Acarbose. Drugs, 35, 214-243 (1988)

Elfalleh W, Hannachi H, Tlili N, Yahia Y, Nasri N, Ferchichi A. Total phenolic contents and antioxidant activities of pomegranate peel, seed, leaf and flower. J Med Plants Res, 6, 4724-4730 (2012)

Havens K, Kramer AT, Guerrant Jr EO, Herendeen PS. Getting plant conservation right (or not): The case of the United States. Int J Plant Sci, 175, 3-10 (2014)

Hernandez-Rodriguez P, Baquero LP, Larrota HR. Flavonoids: Potential therapeutic agents by their antioxidant capacity. In: Bioactive Compounds, Woodhead Publishing, awston, England, p 265-288 (2019)

Hu Y, Wang S, Wang A, Lin L, Chen M, Wang Y. Antioxidant and hepatoprotective effect of Penthorum chinense Pursh extract against $t$-BHP-induced liver damage in L02 cells. Molecules, 20, 6443-6453 (2015)

Islam S, Nasrin S, Khan MA, Hossain AS, Islam F, Khandokhar P, Mollah MNH, Rashid M, Sadik G, Rahman MAA, Alam AK. Evaluation of antioxidant and anticancer properties of the seed extracts of Syzygium fruticosum Roxb. growing in Rajshahi, Bangladesh. BMC 
Complementary Altern Med, 13, 142 (2013)

Jang TW, Park JH. Antioxidative activities and whitening effects of ethyl acetate fractions from the immature seeds of Abeliophyllum distichum. J Life Sci, 27, 536-544 (2017)

Jayaprakasha GK, Selvi T, Sakariah KK. Antibacterial and antioxidant activities of grape (Vitis vinifera) seed extracts. Food Res Int, 36, 117-122 (2003)

Jo SY. Kim YM. Inhibitory effect of Penthorun chinense extract on allergic responses in vitro and in vivo. J Food Hyg Saf, 30, 376-382 (2015)

Korea Centers for Disease Control \& Prevention. 2019 Chronic Disease Fact Book. Korea Centers for Disease Control \& Prevention, Cheongju, Korea, p 6 (2019)

Korea National Arboretum, Checklist of Vascular Plants in Korea Native Plants. http://www.nature.go.kr./kpni/open yard/notice/selectNoticeDetail.do. (Assessed October 2020)

Kwon JG, Jung YW, Seo C, Hong SS, Choi CW, Lee JE, Shin HT, Jung SY, Kim JK. Analytical method development of (-)- Epicatechin gallate in Penthorum chinense Pursh extract using HPLC. J Soc Cosmet Sci Korea, 45, 87-93 (2019)

Lin LM, Zhao LJ, Deng J, Xiong SH, Tang J, Li YM, Xia BH, Liao DF. Enzymatic extraction, purification, and characterization of polysaccharides from Penthorum chinense Pursh: Natural antioxidant and anti-inflammatory. BioMed Res Int, 2018, 3486864 (2018)

Molyneux P. The use of the stable free radical diphenylpicrylhydrazyl (DPPH) for estimating antioxidant activity. Songklanakarin J Sci Technol, 26, 211-219 (2004)

Padayatty SJ, Katz A, Wang Y, Eck P, Kwon O, Lee JH, Chen S, Corpe C, Dutta A, Dutta SK, Levine M.
Vitamin $\mathrm{C}$ as an antioxidant: Evaluation of its role in disease prevention. J Am Coll Nutr, 22, 18-35 (2003)

Pellegrini N, Ke R, Yang M, Rice-Evans C. Screening of dietary carotenoids and carotenoid-rich fruit extracts for antioxidant activities applying 2,2'-azinobis (3-ethylenebenzothiazoline-6-sulfonic acid radical cation decolorization assay. Methods Enzymol, 299, 379-389 (1999)

Prieto P, Pineda M, Aguilar M. Spectrophotometric quantitation of antioxidant capacity through the formation of a phosphomolybdenum complex: Specific application to the determination of vitamin E. Anal Biochem, 269, 337-341 (1999)

Santos-Buelga C, Gonzalez-Paramas AM, Oludemi T, AyudaDuran B, Gonzalez-Manzano S. Plant phenolics as functional food ingredients. Adv Food Nutr Res, 90, 183-257 (2019)

Xanthopoulou MN, Nomikos T, Fragopoulou E, Antonopoulou S. Antioxidant and lipoxygenase inhibitory activities of pumpkin seed extracts. Food Res Int, 42, 641-646 (2009)

Xia XD, Chen J, Fan S, Gao XL, Li LH, Chen RJ, Zhong $\mathrm{K}$, Gao H, Yamaguchi I, Xu ZJ. Antioxidant activity, DNA damage protection and phenolic contents of Penthorum chinese Pursh. J Med Plants Res, 6, 4292-4298 (2012)

Yehye WA, Rahman NA, Ariffin A, Abd Hamid, SB, Alhadi AA, Kadir FA, Yaeghoobi M. Understanding the chemistry behind the antioxidant activities of butylated hydroxytoluene (BHT): A review. Eur J Med Chem, 101, 295-312 (2015)

Zhang YJ, Gan RY, Li S, Zhou Y, Li AN, Xu DP, Li HB. Antioxidant phytochemicals for the prevention and treatment of chronic diseases. Molecules, 20, 2113821156 (2015) 